Reina Lewis and Sara Mills, eds., Feminist Postcolonial Theory. A Reader

\title{
Anne Castaing
}

\section{(2) OpenEdition \\ 1 Journals}

Electronic version

URL: https://journals.openedition.org/ces/5855

DOI: $10.4000 /$ ces.5855

ISSN: 2534-6695

Publisher

SEPC (Société d'études des pays du Commonwealth)

\section{Printed version}

Date of publication: 1 September 2013

Number of pages: 111-112

ISSN: 2270-0633

\section{Electronic reference}

Anne Castaing, "Reina Lewis and Sara Mills, eds., Feminist Postcolonial Theory. A Reader",

Commonwealth Essays and Studies [Online], 36.1 | 2013, Online since 16 April 2021, connection on 22

July 2021. URL: http://journals.openedition.org/ces/5855 ; DOI: https://doi.org/10.4000/ces.5855

This text was automatically generated on 22 July 2021 .

\section{cc) (†) $\ominus$}

Commonwealth Essays and Studies is licensed under a Licence Creative Commons Attribution - Pas d'Utilisation Commerciale - Pas de Modification 4.0 International. 


\title{
Reina Lewis and Sara Mills, eds., Feminist Postcolonial Theory. A Reader
}

\author{
Anne Castaing
}

\section{REFERENCES}

Reina Lewis and Sara Mills, eds. Feminist Postcolonial Theory. A Reader. New York:

Routledge, 2003. 754 pp. ISBN (hb): 978-0-415-94274-4. £75

1 In the very opening pages of Reina Lewis and Sara Mills' Feminist Postcolonial Theory. A Reader, the luminous text written by poet and activist Audre Lorde and entitled "The Master's Tools Will Never Dismantle the Master's House" bears witness to the volume's triple purpose: to nurture a discussion and a critical reading on hierarchical relations and on modes of oppression; to foster a fertile dialogue, where poetic word, academic discourses and activism respond to each other; to recall through this manifesto that complex theories such as feminism and postcolonial thought are often stimulated by political convictions; that they are born from, or have nourished, activist trajectories which aim at "dismantling" (or, at least, deconstructing) the Master's house.

2 The desire to deconstruct, even to "decolonize," the main theoretical fields of both postcolonial and feminist theories, indeed traverses this volume which, in 2003, decisively imposed itself in the field of criticism at the outcome of a decade (the 1980s) saturated with rich, ebullient, and explosive critical reflection, as shown by the diversity and the vigour of the 28 articles presented here. Divided into six thematic chapters, Reina Lewis's and Sara Mills's volume aims, not at defining the complexity of feminist postcolonial theory, but at locating its struggles, tools, and fields of investigation, through various, and often major texts of feminist postcolonial thought.

3 The first chapter, "Gendering Colonialism and Postcolonialism/Racialising Feminism," discloses the intersectional agenda of this volume. In her seminal article "Under Western Eyes. Feminist Scholarship and Colonial Discourses," Chandra Talpade Mohanty analyses "the production of the Third World Woman as a singular monolithic 
subject in some recent (western) feminist texts" (49), and calls for "decolonizing gender," in other words, deconstructing the universalisms of mainstream Western feminist discourses. This position also nurtures the volume's second chapter, "Rethinking Whiteness," which contains texts written by activists such as Vron Ware and bell hooks, and is concerned with the sources of Black (or postcolonial) feminism in response to the questioning of some feminists on their racial identity and the Western countries' colonial past. The third chapter aims at "Redefining the Third-World Subject" in relation to Gayatri Spivak's seminal thought, and addresses the crucial issues of "diversity of experiences" and "cultures," whose plural itself reveals the significance of such discourse: thinking difference as a singularity and an alternative, thinking Black feminism as a marginal but vivid culture, allows both to perceive oppression as a sprawling and cumulative strategy, and to develop other forms of expression within this system. In her article "Racism, Birth Control and Reproductive Rights," which opens the fourth chapter ("Sexuality and Sexual Rights"), Angela Davis questions these modes of oppression through the prism of birth control in the 1970s, which, far from rallying all women in a common struggle, echoed for Afro-American women slavery and colonial practices which aimed at controlling black women's sexuality and reproduction. The fifth chapter aims at decolonizing "the Harem and the veil" as symbols of both Oriental archaism and mystery, and bespeaks the diversity of veiling practices which have an urgent need to be historicized. Finally, the last chapter, "Gender and Post/Colonial Spatial relationships," questions the complexity of colonial space, the porosity of geographical, theoretical and identity borders in a diasporic world and the creation of new borders and new hierarchies, within feminist thought itself.

Whereas this volume pleads for the dismantling of binarisms and hierarchies (such as North versus South, White versus Black, Man versus Woman, Colonizer versus Colonized), it above all aims at ingraining and historicizing not only experiences and identities, but also modes of thinking. Such a volume, although published a decade ago, is more than ever relevant: at the time of the explosion of feminist (sometimes globalizing) discourses and the crystallization of racial, national or sexual identities, it is indeed imperative to reconsider these discourses and identities which, as Adrienne Rich underlines in this volume, need a "politics of location" which could foreground the relationality of identity formation, and could qualify this "Other" that, as Sara Suleri wrote elsewhere, "critical theory names [...] in order that it need not be further known" (The Rhetoric of English India, 13). Beyond these crucial issues, Lewis and Mills also deplore the way postcolonial criticism has marginalized feminist discourses which, nevertheless, are rooted in a concrete and politicized project that postcolonial theory is said to have lost interest in: "It is the marginalisation and the exclusion of a separate trajectory of feminist thought about race, culture and empire, that this collection seeks to redress: to locate again this history of feminist thinking and activism in relation to mainstream postcolonial theory" (20). In other words, to dismantle the Master's House... 


\section{AUTHORS}

\section{ANNE CASTAING}

Anne CASTAING is a research fellow at the CNRS (Laboratoire Arias, UMR 7172). Her work focuses on contemporary Indian literature, on vernacular writing in a postcolonial context, on literary representations of history (mostly dealing with Partition), as well as on gender issues. She is the editor of Ragmala, Anthologie des littératures indiennes traduites en français (L'Asiathèque, 2005) and the co-editor of La Modernité littéraire indienne : perspectives postcoloniales (PU de Rennes, 2009). She also translates Hindi literature into French. 